\title{
AN INVESTIGATION ON THE HISTORY AND STRUCTURE OF KOREAN SHAMANISM
}

\author{
Arevik CHAČATRJAN (KHACHATURIAN) \\ Charles University in Prague, Department of Ethnology \\ Prague, Czech Republic \\ arevik.ch@gmail.com
}

\begin{abstract}
Korean civilization has been influenced by different religions, such as Buddhism, Taoism, Confucianism and lately Christianity. However, the nucleus of the Korean culture is Shamanism, which is a conjuring religious phenomenon. Even though Shamanism belongs to the first page in the history of religions, it has been transmitted to next generations of Korea in different forms, somewhat surviving until today. A possible reason for this may be that Shamanism exhibits a dynamic and selective tradition that has adapted to different religions around it. It may also provide human beings with the blessings that they are deprived of in today's society. In this study, the origin and development of Shamanism in Korea, including the three dynasties of Silla, Koryo and Yi, were investigated. The primitive forms of ancient beliefs of Koreans as well as the structure of Shamanism and related rituals were described. Information was also provided on Shaman ritualists and the instruments they utilized in rituals.
\end{abstract}

Keywords: Korean Shamanism, Asian religions, Shaman's Ritualistic Instruments, Mudang, Paksu, Kut

\section{VÝZKUM OHLEDNĚ DĚJİN A STRUKTURY KOREJSKÉHO ŠAMANISMU}

Abstrakt: Korejský poloostrov byl ovlivněn různými náboženstvími jako buddhismus, taoismus, konfucianusmus, a v poslední době významnou roli hraje i křest'anství. Nicméně jadrem korejské kultury je šamanismus, který je čarujícím náboženským 
fenoménem. Šamanismus byl prvním náboženstvím v dějinách Koreje, a aby přežil do součastnosti, tak byl předán prríštím korejským generacím v transformované formě, $t j$. $\mathrm{v}$ podobě různých náboženských forem. Tento článek popisuje vznik a vývoj šamanismu na Korejském poloostrově v období dynastií Silla, Koryo a Yi. Rovněž se popisuje struktura šamanismu a s nim související náboženské rituály, šamanské nástroje, které se hojně použivají během rituálů.

Klíčová slova: korejský šamanismus, asijská náboženství, šamanské rituální nástroje, Mudang, Kut

\section{한국 샤머니즘에 관한 역사와 구조 연구}

\section{축약: 한국 문명은 불교, 도교, 유교 그리고 최근 기독교 등 다양한 종교에} 의해 영향을 받아 왔다. 하지만, 한국 문화의 핵심은 종교 현상을 연상시키는 샤머니즘이다. 샤머니즘이 종교사의 첫페이지를 장식함에도 불구하고, 여러 형태로 한국 후세에게 전해져 내려와 오늘날까지 특정한 형태로 살아 있다. 이 연구는 한국의 샤머니즘의 기원과 발전에 관한 것이며 신라를 포함한 삼국 시대 왕국, 고려, 조선을 조사했다. 한국의 고대 신앙의 원시적 형태는 샤머니즘과 관계된 의식으로 묘사되었다. 샤먼들의 의식에 사용되는 악기에 대한 정보도 제공되었다.

키워드: 한국어 샤머니즘, 무교, 아시아 종교, 무당 의식기구, 무당, 굿

\section{Introduction}

Religion plays a unique role in the development of a nation's civilization. It affects not only the point of view of individuals in the community but also shapes the soul of the nation and its destiny. It may be questioned if being influenced by many different religions throughout history is desirable or not for a nation. Surely, this may result in the accumulation of valuable experiences. However, it is also important that the price paid for this gain is not too high and the experiences are not so bitter. Korea is a good example of a place where different religions have become important for the society during different times and even during the same era. Historically, Korean civilization has been primarily shaped by Shamanistic beliefs after when influences of the ideologies of Buddhism, Taoism, Confucianism and lately Christianity have been observed. However, the nucleus of the Korean culture 
is Shamanism, which is a conjuring religious phenomenon regulating the fortunes of nature and man through intercourse with supernatural divine spirits. A comprehending definition of Shamanism has been given as a traditional, religious phenomenon tied closely to nature and the surrounding world, in which a practitoner endowed with the special ability to enter a state of trance-possession can communicate with supernatural beings (Kim 1998: 15-31). The practitioner is the shaman who tries to satisfy human cravings for explanation, understanding and prophecy.

The aim of this study was to investigate the origin and development of Shamanism in Korea, including the three dynasties of Silla, Koryŏ and Yi. The primitive forms of ancient beliefs of Koreans as well as the structure of Shamanism and related rituals were described.

\section{Prototype of Korean Shamanism}

It is difficult to determine the origin of Korean Shamanism (Eliade 1964) as well as to identify its prototype. Today's Shaman customs have been mixed with foreign elements and have undergone various changes. Original Shamanism must rather be found in ancient beliefs, such as myths and rituals before foreign influences took place. Fortunately, information about some myths of ancient times has been transmitted to us through various records. One of these is the Myth of Tangun which refers to God and the belief in his coming from heaven to earth resulting in the union of heaven and earth and creation (Tongshik 2012: 35). Accordingly, heavenly God married the goddess mother of earth who was actually re-born as a human being and before then was a she-bear. Through the union of God and human being, a new life was created, that is the son of God. This also indicates that a new world was created in the form of a nation. Chumong and Hyŏkkŏse are other examples of myths which used more or less similar symbols describing ancient beliefs. 
In order to understand the beliefs of ancient Korean people, it is also necessary to investigate their rituals. These rituals may be primarily grouped in three sections (Tongshik 2012: 62-78). The first one is the sacrificial offering ceremonies and the belief in light, which also symbolizes heavenly God. People offered sacrifices to the Heavenly God and welcomed him with song and dance in these ceremonies. An example is Yŏng-go (Welcoming Drum) that took place in the harvest month. As a farming culture started to develop in Korea, ceremonies also started to change. Thus, the second group of rituals is related to agriculture and the belief in grain goddess. Here, agricultural rituals took place in which sacrifices were offered to the goddess mother of earth. The third ritual concerns exorcising with singing and dancing and the belief in creation. In these events, people sang and danced with food and drink for many days and nights. The religious significance was to lead the people into a group ecstasy so that they could experience union with God.

Actually, we can find the prototype of Korean Shamanism by readjusting the structure of ancient beliefs as indicated by the rituals and myths. This should be as follows:

\begin{tabular}{|c|}
\hline $\begin{array}{c}\text { Descent of Heavenly God } \\
\text { (Comes in the form of light or sends his son) }\end{array}$ \\
\hline $\begin{array}{c}\text { Sublimation of Goddess Mother of Earth } \\
\text { (Self-abandonment for direct contact with God, } \\
\text { through drinking, singing and dancing) }\end{array}$ \\
\hline \hline Fusion of Heaven and Earth \\
(Realizing man's wishes, such as bountiful harvest or \\
victory in battle by union with God through certain rituals)
\end{tabular}




\section{Origin and Development of Shamanism in Korea}

Shamanism has existed on the Korean peninsula since the archaic period (before 1,000 BC). First written records about Shamanism are at about the third century in the chinese text Wei Chi (Tongshik 1984: 8). Foreign religions, such as Buddhism, Taoism, Confucianism and much later Christianity have started to become dominant, especially in the elite upper class, with passing time. In spite of all, Shamanism did not disappear and continued to exist along the other religions. It continued its popularity, especially with females and poorer people, and was transmitted to next generations. The means of transmisson can be classified into three (Tongshik 1984: 9-10). The first one was a simple transmission of Shamanism with time, mainly through personal or village ceremonies. In this case, the influence of foreign religions on the transmission of beliefs and practices of archaic Shamanism was superficial and without fundamental changes. The second type of transmission was syncretistic. This means that Shamanism was incorporated into the beliefs and practices of the other religions, Buddhism (Kim 2003: 1254-1256), Taoism, Confucianism and Christianity (Hyuck 2004), while replacing some of essential substance or meaning of these religions with its own. The third one was sublimated transmission, which involved the formation of different, new religions by the mixing of Shamanism with other established religions.

The development of Korean Shamanism may be understood better by the investigation of its status in the three royal dynasties of Silla (356-935), Koryŏ (918-1392) and Yi (1392-1910) that have ruled in Korean territories (Tongshik 2012: 94-125). The golden age of Silla culture was between 6th and 8th centuries when territorial unification was achieved for the first time in Korean history. Buddhism which was introduced from China helped Silla to build up a higher standard of civilization. There were great monks, such as Wŏnhyo (618-686), Ǔisang (625-702) and Wonch'ŭk (613-696) during this period. Actually, the ancient sacrificial rites of Shamanism continued in different forms in the Silla Dynasty. Different forms of transmission took place. As examples of simple transmission, the mountain and river festivals, ancester festival and rain prayer festival of Silla can be 
mentioned. Partial transformation was also observed in the elements of Shamanism. P'algwan-hoe (Harvest festival), Yŏndŭng-hoe (Lantern festival) are good examples of this syncretistic type of transmission. P'algwan-hoe was initiated during Silla dynasty and continued in Koryŏ dynasty. It was held in Buddhist temples but was not really a Buddhist worship. It involved singing and dancing like those in ancient festivals. Yŏndŭng-hoe was held during Silla and Koryŏ dynasties with candles in lanterns kept burning all night on the 15 th and 16th of the first moon each year. The lantern was burning to Buddha of the universal light but this had similarities with worshipping the dragon and bright light in ancient times. There was also music and dancing similar to ancient Shaman traditions. In the Silla Dynasty, the union of Shamanism with foreign religious cultures to create a new religious culture was also observed. Hwarangdo (Knighthood of Flower Youths) might be given as an example of sublimated transmission during this period. Hwarangdo was a creative combination of Shamanism with higher standard religions but the main body was Shamanism. King Chinhŭng of Silla decided to train a new order of young leaders. He set up a new system, Hwarangdo, to train them into youths of self-identity, keeping the traditional culture and also absorbing Buddhist and Chinese cultures. However, it disappeared with the ruin of Silla Dynasty.

The golden age of Koryŏ culture was during King Munjong (1046-1083) and King Yejong (1105-1122) (Tongshik 2012: 162206). Buddhism became the state religion and the religious belief of especially the nobles. The intellectual background was a mixture of Buddhism, geomancy and traditional Shamanism. Geomancy can be described as a mixture of Yin and Yang relationships and divinations coupled with geographic features. It was an eclectic religious idea believing in gods of mountains and streams, gods of Buddhism and gods of Shamanism. On the other hand, Taoism was also officially recognized in the 12th century by King Yejong. Buddhism, Taoism and geomancy had a common idea of Shamanism at their bases. Similar to Silla, different forms of transmission of Shamanism were observed during the Koryŏ Dynasty.

Mountain and river festivals, ancester festival, rain prayer festival were examples of simple transmission while P'algwan-hoe and Yŏndŭng-hoe were examples of syncretistic transmission. In 
addition, it should be mentioned that a rise in Shamanism belief was seen in Koryo after the reign of Injong (1122-1146). A new form of Shamanism evolved, represented by the witch and wizard (Mudang) custom with weird music and dance.

During the Yi Dynasty, a governmental changeover to Confucianism occurred. King Sejong (1418-1450), King Songjong (1469-1494) and King Chungjong (1506-1544) were central figures. King Sejong established the Chiphyŏnjŏn (Royal Academy), developed Hunmin Chŏng'ŭm (a phonetic writing of 11 vowels and 17 consonants), with rich achievements of culture. At the same time, he was responsible of the Confucianization of the state while oppressing Buddhism. Although Yi Dynasty seemed to be a Confucian state, this was mainly centered on the ruling classes of male society while the base of the culture consisted of traditional religions, Shamanism, Buddhism and Taoism which still flourished among masses especially in female society. As also observed in Silla and Koryŏ, Shamanism of Yi Dynasty evolved by transmission. The simple folklore type of ancient rituals, offering sacrifices to gods of heaven and earth, mountains and rivers as well as ancester worship, which appeared in rites of rain prayers wishing for rich harvests, represented simple transmission (Tongshik 2012: 236-250).

An interesting ritual in the Yi Dynasty was the plague-chasing ritual (Eliade 1964) which may be classified as a syncretistic transmission of Shamanism. The plague-chasing ritual was introduced from China and was conducted on New Year's Eve in the royal palaces to chase away devils and ghosts of all plagues. In outer appearence it was a Chinese custom but it conserved the old native Shamanist ideology of chasing away devils and welcoming happiness. Therein, the traditional Ch'oyong dance of Shamanism was performed. As an example of sublimated transmission in the Yi Dynasty, the Tonghak (Eastern Learning) movement may be shown (Tongshik 2012: 274). It was formed by Ch'oe Che-u and rose in rebellion against the ruling classes in 19th century. It was an esoteric combination of Confucianism, Buddhism, Taoism, Catholicism, and native Shamanism. The peasant population welcomed this native-born doctrine which held all the potential for revolution. Additionally, the wizard belief became more fashionable in the Yi Dynasty and made some developments, especially in a set-pattern of mudang costumes. 
Even though Shaman belief was prohibited by Confucian officials as a superstitious religion, Shamanism ruled the conscience and life philosophy of the masses. On one hand, mudangs were expelled from the capital while they were also mobilized in prayers for rain, for grace and in plague-chasing rituals.

\section{Structure of Ancient Korean Shamanistic Beliefs}

According to Shamanistic belief, one must be able to persuade the gods to control things as one wishes. People tried to do this through certain rituals. In these ceremonies, they invited the gods, entertained them, listened to their will and obeyed them. The ceremonies had three main aims:

1) To bring blessings and prevent evil fortune

2) To expel evil spirits and have diseases cured

3) To comfort and purify the souls of the dead in order to send them to the other world without causing disasters in this world.

The typical rituals of Shamanism are called kut (Tongshik 1984: 11; Kister 1997). The kut is performed at times of change, either in human life or in seasons. With regards to personal concerns, it takes place when a baby is to be born, when the baby matures and reaches the point of marriage, when there is a need for praying for a long and happy life and finally when the person dies. The kut is also performed during annual cycle of seasonal changes that affects agriculture. For example, ceremonies are held during spring (time for planting) to pray for good fortune during the year. The harvest is offered to heavenly God.

Large-scale kut usually consists of twelve sequences. Just as twelve months make a complete year, it seems that twelve of these sequences make a complete ritual, or a "full course" of kut (Tongshik 1984: 12). There are also simpler kut aimed mainly at preventing disasters. The sequences of the kut generally include the following: 
1 and 2: Introductory sequences to purify the place of the ritual and call down a host of Gods,

3: A prayer for protection,

4: Expulsion of evil spirits,

5: Taegam, the deity of richness, is invited and prayer is made for blessings of wealth,

6: Chesŏk, the Buddhist Heavenly God, is invited and prayer is made for long life,

7: Sŏngju, the heavenly deity who supervises the world, is invited and prayer is made for peace,

8 and 9: Prayers are again made for protection and for expulsion of evil spirits as in Sequences 3 and 4,

10, 11, and 12: The shaman worships the guardian Gods and offers sacrifices to various spirits so that there may be no evil consequences.

During the ceremony, firstly, the Shaman calls down the God who is the object of the ritual by singing an invitation to worship. Then the Shaman starts to sing and dance to a special tune and rhythm accompanied by instruments playing Shaman music to please the God who is invited. The pace of the singing and dancing increases until it reaches a frenzied point and the Shaman goes into trance. In this ecstatic state, the Shaman is in direct communion with the God and conveys the words of the God to those watching the ceremony. Those words may be warnings or commands, or they may be promises of blessings to be received. When this is over the Shaman sends the God back to its place by singing songs of praise and by dancing.

It should be noted that the medium of direct communication with the Gods is that of song and dance. Entrance to the world of the spirits is through rhythms of the body, not through meditations of the mind. The structure and principles of Shamanism involve balance. The objective of the kut is to restore balance through the unification of heaven, earth, and people.

There are some differences in cultural symbols and formalities between Korean Shamanism and Shamanism in other societies of northeastern Asia (Tongshik 2012), although the structure is generally the same. For example, during the Shaman meeting with spirits, the Tungus Shamans fly away while the Koreans and Japanese call down 
the spirits. Furthermore, the nuclei of the rites of the Tungus and Japanese are in the offering of sacrifices to gods and in the relay of the gods' oracles, respectively. However, the Korean kuts entertain gods with song and dance before receiving the oracles. Another point is the difference in the emphasis on the functions of the kuts. The Japanese are concentrated on the send-off and peaceful repose of the dead soul while the Koreans focus on invocations of positive blessings from the gods whom they entertain in turn.

\section{Shaman Ritualists}

In all primitive religions with no founder, the position of a ritualist stands for the founder. In Shamanist belief, the chief is the Mudang, which is a name for all exorcists but women in particular. Often, the representative name for a male exorcist is Paksu (Tongshik 2012: 411). We can see the start of the male Shaman in the myth of Tangun. During the age of theocracy, the male Shaman performed the functions of both religion and the state. However, female Shamans took the initiative for religion when the governing of state and religion were separated at the times of the start of Christian era.

The Shaman is a practitioner exhibiting trance, ecstasy and possession (Kim 1998: 15-31). Trance involves interaction with supernatural beings through hallucinations, visions or dreams often by sending the soul on a journey to hear and interact with spirits while retaining the identity (Kim 1998: 45-54). Trance is generally induced by hypoglycaemia, brought on by fasting, sensory deprivation, isolation, mortification or hallucinogens. Ecstasy and possession originate from a trance leading to an altered state of consciousness. Ecstasy is a means of communication between the Shaman and spirits in this altered state of consciousness. Possession indicates that there is an exchange of spirits, concerning the Shaman's body, during the trance. It can be divided into spirit-possession and trance-possession which signify that the soul leaves the Shaman's body and spirits from outside enter the Shaman's body, respectively. Trance-possession is 
usually induced by drumming, singing, dancing, crowd contagion or, more rarely, drugs (Kim 1998: 45-54). It is a public performance requiring an audience. In short, the Shaman is endowed with the very special gift of trance-possession and communicates with the supernatural world, thus being able to deliver oracles and fulfill human aspirations.

Shamans are classified into three according to their state of initiation (Tongshik 2012: 412-421). The spirit-possessed Shamans have communication with descending spirits, perform exorcising rites with song and dance, declare oracles of their god or goddess, divine the causes of singular maladies and pick a lucky day for exorcism. Hereditary Shamans may be regarded as trainees who have no experience of possession by a descending spirit. They sing and dance but never declare an oracle and simply act as ritualists rather than having communication with descending spirits. These Shamans are skillfull in singing and dancing and performing exorcism. The last type is called apprentice. Actually, these learn their art for a living, so they are regarded as suspect or imitation Shamans. The Shaman system is often transferred to the next generation but the succession of Shamanism is not necessarily due to blood relationships. More successions occur by spiritual relationships, such as those between a god-mother and god-daughter by adoption.

In the first two types of Shamans mentioned above, the number of female Shamans is always higher than male Shamans (about $70 \%$ of total). There were about 2600 Shamans during the rule of King Sunjo (1800-1834) in Yi Dynasty. In 1930, this number was 12380 (68\% mudangs, 32\% paksus). Even now there must be some thousands of them throughout Korea.

\section{Ritualistic Instruments}

Most ritualistic instruments of korean shamans are simple, as taken from natural objects and common household items. These instruments 
may be investigated in five distinct categories as described below (Lee 1981: 81-88).

1) Instruments dealing with an altar

These types of instruments include straws, pine branches, tables, divine images, folding screens and sacred flags. Straws are used to make huts and ropes, the branches are put on the altar to signify the sacred place and altar area while tables are used to place food on them. There are a lot of pictures of spirits, divine statues, paper and wooden plates on which the names of divine spirits are written. These are divine images symbolizing the spiritual presence at the altar. Various images or pictures of spirits are also seen on folding screens. Flags also have an important place as ritualistic instruments. Flags of five directions are white papers with flower designs attached to bamboo poles and they are placed at the south, north, east, west corners and center of the room where the ritual takes place. A commanding flag is a large, long (about 30 feet of height) flag set up in front of the home of the ascending spirit at the ritual. It consists of a large piece of paper and different colored fabrics, papers, ropes, coins, etc. A flag of descending spirit is about 2 feet in length made of white papers on which the date of the descending spirit is often recorded. The flag of Yongdung god and the flag of primary spirits are used to ask for protection against flood and storms. There are also colored flags of military spirit in green, blue, red, yellow and navy blue.

2) Instruments dealing with charms and oracles

These instruments include beech branches, bamboo poles, cooking knifes, charm symbols, jars and bottles, effigies, high chairs and symbols of birds. The branches and poles are used in the exorcism of evil spirits from mentally ill people and from home, respectively. The cooking knife is believed to remove evil spirits when it is accompanied by the food offered during the ritual. Charm symbols are used to prevent the intrusion of evil spirits during the ritual. Jars and bottles are utilized to catch evil spirits that cause illness and unrest at home. Effigies are made of papers or straws and are used to replace the sick or dead. In case of the sick for example, the effigy is placed on the 
river and is allowed to drift away, symbolizing the dismissal of the illness. A high chair is also used in the rituals for the exorcism of evil spirits from a mentally ill patient. It has a straw basket at the top where the patient is placed during the ritual so that he cannot escape. Symbols of birds may be seen at the location where the ritual takes place. As an example, the picture of a three-headed duck is hung on the wall or the ceiling to prevent the coming of great disasters.

\section{3) Musical instruments}

Since there is a lot of singing and dancing at the Shamanistic rituals, musical instruments have an important place therein. Drums, bells, gourds, gongs, flutes and a brass instrument made of two pieces to be clapped together make the musical sounds during the ritual. Drums are made of a natural wood and has cow skin on both sides. Different types of drums are used by Paksus and Mudangs. The bells, generally made of brass or other metals, are believed to bring the attention of spirits while gongs have the power to call spirits to the ritual. A sounding bag is another means to produce sound and is used to replace a small drum when Mudang calls out the spirit of the dead.

\section{4) Instruments dealing with divinations}

Certain objects are used as divine symbols during the Shamanistic rituals. Five pieces of wood, for example, represent fire, water, wood, metal and earth. Counting cyrinda is an object made of brass or wood. Eight pieces of wood are placed in an opening at the top and during divination one is taken out at a time. When three are taken, their numbers are added to arrive at the number of a hexagram in the Book of Changes. Counting tortoise has the shape of a tortoise and is made of wood or metal. Coins are kept in it. During divination three coins are taken out to determine fortune or misfortune, on the basis of which side appears. Sacred swords are thrown onto the ground during the prayer. When they all fall pointing to the same direction it is a sign of good fortune. Additionally, when a large sword touching a table is released and it stands, this is regarded as a good sign. Rice powders are used in the ritual of the dead. The powders are placed in a bowl with a paper effigy of the dead at the top. When footprints of birds or 
animals are found on the powders after the prayer, it signifies the reincarnation of the soul of the dead.

\section{5) Offerings}

Most often, beef, pork, dressed fish, beverages and cake (made of wheat, flour, oil and honey) are presented for sacrifices during the rituals.

\section{Conclusions}

Shamanism has started in ancient times in Korea and has stayed in existence since then, mixing with other religions. It has been suppressed and even suffered severe insults along the history of Korea. However, Shamanism has survived until now because since contemporary Shamanism incorporates Buddhism, Taoism and Confucianism (and arguably even Christianity), it exhibits a dynamic and selective tradition that has adapted to different religions around it. Another reason of its survival is that human beings want to be blessed ever more and Shamanism may provide this. Shamanism teaches that blessings come only as balance is restored. People pray for each other's blessings, and share food and dance together according to Shamanistic principles.

Surely, there may be some negative aspects of Shamanism, such as the presence of superstition, magical powers and no ethical dimension. However, its positive aspects are also noteworthy. Poor and powerless people can relate themselves to Shamanism easily. It heals the wounds of oppression for simple people. It does not require long periods of meditation or intellectual training so that it does not seem to be unreachable. Additionally, Shamanism is a driving force in the creation of folk culture, such as song, dance, drama, art and philosophy.

Even though Shamanism belongs to the first page in the history of religions, the possibility of creating a new civilization may 
still be found in its dynamics. It may provide some liberation from the bonds of history and ego of man, which may give a chance for the creation of a new world of peace. A crucial point is that a correct understanding of Shamanism is required. Otherwise, Shamanism, despite its persistence, may not survive for more than a few more generations.

8. Bibliography

Eliade, Mircea. 1964. Shamanism: Archaic Techniques of Ecstasy. Princeton University Press.

Hyuck, Jang Nam. 2004. Shamanism in Korean Christianity. Jimoondang, Seoul.

Kim Hogarth, Hyun-key. 1998. Trance and Possession Trance. in: Korean Shamanism (Ed. Keith Howard), Seoul Press, Seoul, pp. 45-54.

Kim Hogarth, Hyun-key. 2003. Syncretism of Buddhism and Shamanism in Korea. The Journal of Asian Studies, 62 (4), 12541256.

Kim, Tae-gon. 1998. What is Korean Shamanism? in: Korean Shamanism (Ed. Keith Howard), Seoul Press, Seoul, pp. 15-31.

Kister, Daniel A. 1997, Korean Shamanist Ritual. Seoul.

Lee, Jung Young. 1981. Korean Shamanistic Rituals, Mouton Publishers. The Hague.

Tongshik, Ryu. 1984. Shamanism: The Dominant Folk Religion in Korea. Inter-Religio 5, 8-15.

Tongshik, Ryu. 2012. The History and Structure of Korean Shamanism. Yonsei University Press, Seoul. 
International Journal of Korean Humanities and Social Sciences, vol. 1/2015 